\title{
EFEKTIVITAS FUNGSI PENGAWASAN DPRD DALAM PELAYANAN PUBLIK
}

\author{
Syaiful Anam ${ }^{1}$; Khairil Anwar ${ }^{2}$ \\ ${ }^{1,2}$ Jurusan Administrasi Publik Fakultas Administrasi Universitas Madura \\ Email: masanam.fiaunira@gmail.com; a2novic@gmail.com
}

\begin{abstract}
Abstrak: Konsep check and balances secara normatif pada sistem pemerintah memiliki makna lebih dari sebatas pembagian struktur kekuasaan, lebih dari itu pembagian kekuasaan adalah penterjemahan kewenangan masing-masing pilar kekuasaan yakni bidang eksekutif berperan sebagai eksekusi program kebijakan dan legislatif sebagai fungsi kontrol dalam penyelenggaraan pemerintahan yang terdistribusi ke dalam ranah aktualisasi kinerja secara implemetatif pada sektor publik secara optimal dan nyata. Efektivitas fungsi pengawasan DPRD pada konteks penyelenggaran pemerintahan di daerah merupakan variabel kunci atas pelaksanaan program kerja dalam pelaksanaan pembangunan daerah, terutama dalam peningkatan sarana kualitas layanan publik yang memadai, responsif, mudah diakses oleh masyarakat daerah. Amanat UU No. 25 Tahun 2009 tentang Pelayanan Publik, secara implisit menegaskan pengawasan pelayanan publik bisa dilaksanakan oleh pengawas eksternal. Efektivitas pengawasan atau kontrol dipengaruhi oleh sistem kontrol baku yang terukur pada unsur input, proses, output yang dicapai. Penggunaan metode pengawasan memeliki pengaruh penting untuk menentukan capaian proses pengawasan itu sendiri, apakah itu dengan metode preventif atau represef. Metode penelitian menggunakan deskriptif kualitatif dengan teknik pengambilan informan purposive sampling.Pada kenyataanya mekanisme kontrol atau pengawasan DPRD terhadap pelayanan publik di Kabupaten Pamekasan kadang kala terhambat oleh faktor intrinsik misalnya, faktor internal institusi menyangkut keterbatasan kuantitas aparatur tenaga teknis dalam membantu anggota legislatif menjalakan kinerjanya, terkooptasi oleh hirarki kebijakan sebagai legal standing anggota legislatif melakukan pengawasan, dan faktor iklim politik parlemen yang terbelah pada poros koalisi dengan oposisi. Disisi lain, kontrol atau pengawasan yang dilakukan oleh alat kelengkapan DPRD komisi-komisi sebagai mitra kerja organisasi perangkat daerah harus di dukung oleh aspek hukum yang kuat, didukung pendanaan yang cukup untuk melaksanakan tugas dan fungsinya, didukung fasilitas yang memadai dan didukung oleh tim sekretariat dewan.
\end{abstract}

\section{Kata Kunci: Fungsi Pengawasan; DPRD; Pelayanan Publik}

Abstract: The concept normative of checks and balances in government systems have more meaning than
the distribution of power structures, more than that the distribution of power is the authority of each
pillar of power such as the executive sector which has a role as the execution of policy and legislative
programs as control function in governance administration distributed into the realm of performance
actualization implemetatively in the public sector in an optimal and real way. The effectiveness of DPRD
administrative supervision on the coordination of governance in the regions is a key for work programs
implementation in regional development implementation, especially in improving the quality of public
services that are adequate, responsive, easily accessible to local communities. Mandate of Law No. 25 of
2009 concerning Public Services, implicitly emphasizes that supervision of public services can done by
external supervisors. The effectiveness of supervision or control is influenced by the measured standard
control system on the input elements, processes, and outputs achieved. Monitoring using methods has an
important influence in determining the achievement of the monitoring process itself, whether it is by
preventive or repressive methods. The research method uses qualitative descriptive and for taking
informant by using purposive sampling. In reality control mechanism or DPRS supervision of public
services in Pamekasan Regency is sometimes hampered by intrinsic factors, for example, internal
institutional factors concerning the limited quantity of technical apparatus in helping legislators run their
performance, co-opted by the policy hierarchy as a legal standing legislative member oversees, and the 


\section{REFORMASI}

ISSN 2088-7469 (Paper) ISSN 2407-6864 (Online)

Volume 10 Nomor 1 (2020)

political climate factor of the parliament which is divided on the axis of coalition with the opposition. On the other hand, the control or supervision done by the DPRD apparatus as a working partner of the regional apparatus organization must be supported by strong legal aspects, supported by sufficient funding to carry out its duties and functions, supported by adequate facilities and supported by the council secretariat team .

\section{Keywords: Supervision Function; DPRD; Public Services}

\section{PENDAHULUAN}

Konsep pengawasan secara umum adalah "supervision is a foreseeing action whereas earlier concept of control was used only when errors were detected. Management supervision is means setting standards, measuring actual performance and taking corrective action. Thus, control comprises these three main activities" (pengawasan adalah suatu tindakan meramalkan lebih dini mengingat konsep pengawasan hanya digunakan ketika kesalahan-kesalahan dideteksi. Secara harfiah arti pengawasan dalam konsep manajemen mencakup tatacara, standar, pengukuran kinerja aktual, dan mengambil tindakan perbaikan.

Pada sektor publik (Negara) sebagaimana kita ketahui, DPR pada prinsipnya memiliki 3 fungsi, yakni fungsi anggaran, fungsi legislasi dan fungsi pengawasan. Ketiga fungsi tersebut sesungguhnya tidak bisa dipisahkan begitu saja karena saling terkait. Misalnya dalam konteks penelitian ini bahwa DPRD Pamekasan setiap tahun anggaran tentu menjadi bagian penting dalam pengesahan keungan pemerintah daerah (APBD). Setelah anggaran disahkan, maka dibentuklah Peraturan Daerah (PERDA) tentang anggaran tersebut sehingga bisa segera dilaksanakan. Lalu untuk mengawal pelaksanaan anggaran agar sesuai dengan standard dan prosedur yang telah ditetapkan sehingga target pembangunan bisa tercapai, maka fungsi pengawasan menjadi penting, baik yang bersifat preventif maupun represif. Namun dalam konteks penelitian ini penekanannya lebih pada fungsi pengawasan.Sehingga tentu point-point yang ada lebih mengarah pada hal tersebut.

Fungsi Pengawasan oleh DPRD merupakan kewenangan institusi parlemen untuk melakukan kontrol terhadap pelaksanaan kebijakan dan kinerja pemerintah daerah termasuk juga dalam hal pelayananan publik. Institusi parlemen sebagai fungsi check and balances diharapkan mampu mendorong eksekutif dalam peningkatan kualitas pelayanan publik di daerah yang lebih responsif.

Bentuk pelaksanaan pengawasan DPRD terhadap pelayanan publik di di berbagai daerah pada umumnya seringkali dengan menggunakan model direct control pengawasan langsung seperti pemanggilan, sidak pada objek yang dituju. Model direct control merupakan kategori pengawasan represif lebih mudah dilakukan serta lebih efektif. Seperti halnya dalam penelitian ini DPRD Kabupaten Pamekassan dalam fungsi pengawasanya cenderung melakukan pengawasan langsung terhadap eksekutif sebagai mitra kerja berupa inspeksi pada objek, pemanggilan dan rekomendasi langsung. Tentunya efektif atau tidak pengawasan yang dilakukan bukan sekedar dinilai dari dimensi cara atau model yang dipilih dalam proses pelaksanaan pengawasan yang dilakukan. Sesuatu dinilai efektif manakala program tersebut memenuhi kriteria output (keluaran) dan outcome (hasil) yang dicapai. Seperti halnya dalam penelitian ini untuk mengetahui efektivitas fungsi pengawasan DPRD dalam meningkatkan kualitas pelayanan publik di daerah Kabupaten Pamekasan.

\section{METODE PENELITIAN}

Penelitian ini memilih pendekatan penelitian deskriptif-kualitatif dengan menggambarkan faktafakta tentang masalah yang diselidiki sebagaimana adanya, diiringi dengan interpretasi yang kuat 


\section{REFORMASI}

ISSN 2088-7469 (Paper) ISSN 2407-6864 (Online)

Volume 10 Nomor 1 (2020)

(Nawawi, 1998:64). Metode pengumpulan data melalui prosedur purposive sampling, dibantu oleh informan kunci (key forman) yang dipilih secara proporsional yang mampu memberi informasi utama dalam faktual yang relevan sesuai kebutuhan penelitian. Key informan dalam riset ini adalah Ketua DPRD Kabupaten Pamekasan yang selanjutnya berkembang berdasarkan informasi dari key informan yaitu: Anggota komisi (DPRD). Kepala bagian persidangan, kepala bagian perundang undangan sekretariat DPRD Pamekasan. Kelompok NGO sebagai pihak yang senantiasa mengikuti dan mengkritisi kebijakan dan kegiatan DPRD kabupaten Pamekasan periode 2014-2019.

Dokumen yang menjadi data yang berkaitan dan menjawab fokus penelitian ini meliputi: (1) Peraturan DPRD Kabupaten Pamekasan Nomor: Tahun 2012; (2) Draft Rencana Kerja (Renja); (3) Lampiran Keputusan DPRD Kabupaten Pamekasan; (4) Pamekasan Dalam Angka; (5) Undang Undang No. 23 tahun 2014 tentang Pemerintahan Daerah.

\section{HASIL DAN PEMBAHASAN}

Harus diakui bahwa fungsi pengawasan merupakan fungsi terakhir yang ditempatkan oleh hampir setiap ahli dalam menggambarkan proses manajemen, tetapi tidak berarti bahwa pengawasan itu selalu dilakukan pada saat suatu kegiatan sudah berakhir (diselesaikan). oleh karenanya pengawasan sesungguhnya berlangsung bersamaan dengan saat penyusunan rencana oleh perencana. Kenyataan bisa kita lihat bahwa penyusunan dokumen Rencana Pembangunan Jangka Menengah Daerah pada suatu daerah oleh Badan Perencanaan Pembangunan Daerah, katakanlah, tidak mungkin sekali dibuat langsung selesai.

Perencanaan tersebut berlangsung dalam suatu kurun waktu lama dan menyita tenaga. Ketika selesai membuat rancangan dokumen rencana, maka dokumen tersebut terlebih dahulu masuk pada rapat plenokan internal untuk mendapat masukan-masukan dari peserta yang sifatnya terbatas. Dengan mempertimbangkan masukan-masukan yang diperoleh dari hasil pleno terbatas tersebut selanjutnya digunakan untuk menyempurnakan dokumen rancangan rencana itu. Setelah dianggap cukup, dokumen rancangan selanjutnya masuk pada tahap seminar melalui suatu forum yang biasanya disebut forum Musyawarah Perencanaan Pembangunan Daerah (MUSRENBANGDA) dengan mengundang elemen masyarakat sebagai peserta dengan tujuan agar mereka dapat memberikan masukan yang lebih banyak lagi.

Berdasarkan masukan dari forum inilah dokumen rancangan rancana mulai dilakukan finalisasinya. Kemudian, dokumen dinyatakan betul-betul final setelah mendapat pengesahan baik melalui suatu peraturan daerah (PERDA) maupun melalui suatu Keputusan Bupati (Perbub). Hal ini berarti pengawasan dipahami sebagai suatu pertanggungjawaban moral dan politik anggota DPRD pada publik yang menjadi konstituennya mengingat keberadaan anggota DPRD sebagai wakil rakyat setelah mendapat legitimasi rakyat melalui pemilihan umum, meskipun secara politik prosedural proses pencalonannya dilakukan oleh partai politik.

\section{Menentukan Agenda Pengawasan}

Perencanaan yang baik merupakan sukses awal pelaksanaan tugas pokok dan fungsi. Oleh karena itu, penyusunan perencanaan tentang kegiatan Pengawasan DPRD yang akan dilakukan merupakan langkah yang sangat penting dan menentukan efektivitas pengawasan yang akan dilakukan. 


\section{REFORMASI}

ISSN 2088-7469 (Paper) ISSN 2407-6864 (Online)

Volume 10 Nomor 1 (2020)

Tabel 1. Contoh Agenda Pengawasan (Minimal)

\begin{tabular}{|l|l|l|c|}
\hline \multicolumn{4}{|c|}{ AGENDA PNGAWASAN DPRD Propinsi/Kab/Kota.... } \\
\hline Obyek Pengawasan & \multicolumn{1}{|c|}{$\begin{array}{c}\text { Tingkatan } \\
\text { Pengawasan }\end{array}$} & $\begin{array}{c}\text { Sumber Daya } \\
\text { Pengawasan }\end{array}$ & $\begin{array}{c}\text { Waktu } \\
\text { Pelaksanaan }\end{array}$ \\
\hline Pelaksaan Perda - Y & Program & Pleno & $\ldots \ldots \ldots \ldots$ \\
\hline $\begin{array}{l}\text { Pelaksanaan Belanja } \\
\text { Daerah - W }\end{array}$ & Proyek & Komisi X & $\ldots \ldots \ldots \ldots$ \\
\hline Pelaksanaan Perda - Z & Kebijakan & Komisi X & $\ldots \ldots \ldots \ldots$ \\
\hline \multicolumn{1}{|c|}{-dst- } & \multicolumn{1}{|c}{-dst- } & $-d s t-$ & $-d s t-$ \\
\hline
\end{tabular}

Sumber: diolah peneliti 2019

Kemudian langkah selanjutnya menentukan teknik pengawasan yang hendaknya diawali dengan mengumpulkan informasi awal, kemudian mengumpulkan informasi dan kondisi aktual di lapangan serta melakukan analisa, dan diakhiri dengan menyusun rekomendasi atas hasil analisa. Urutan teknik pengawasan secara umum dapat digambarkan oleh gambar berikut:

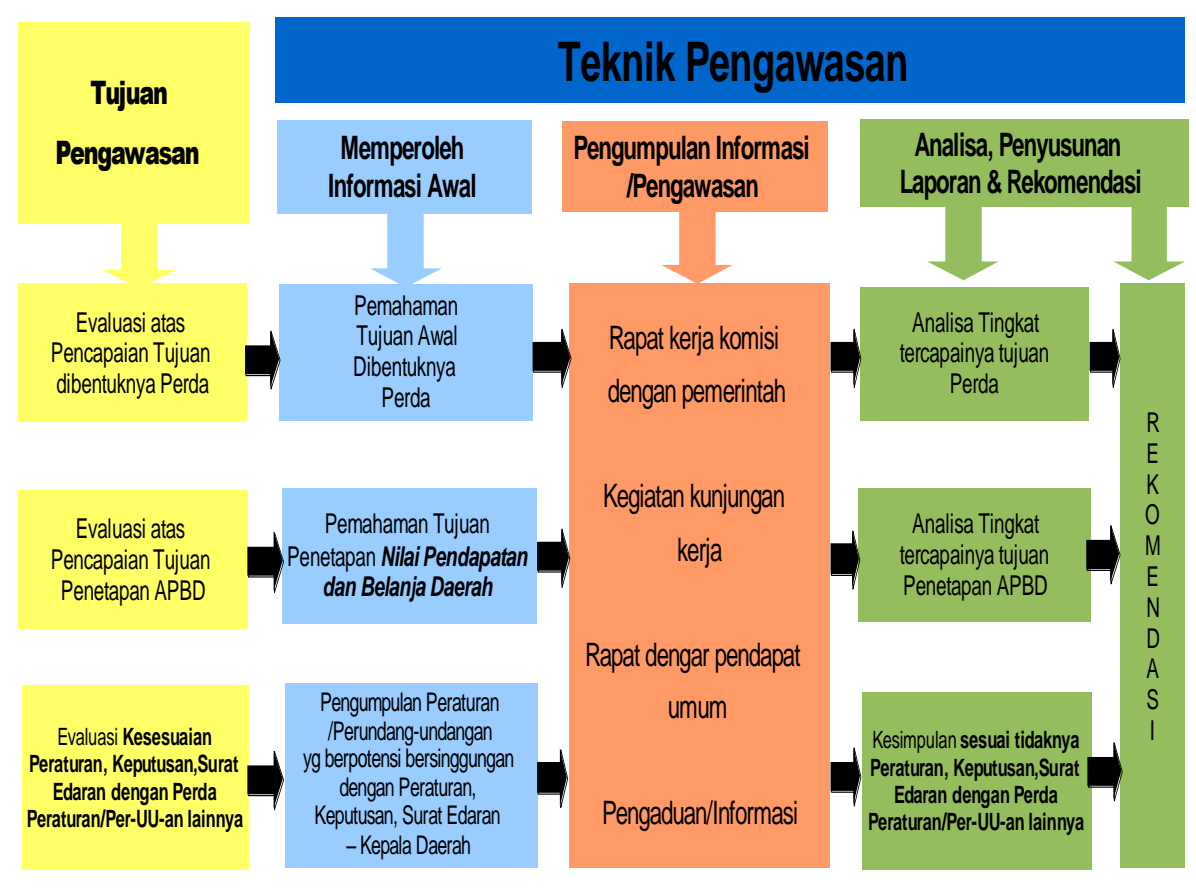

Gambar 1: Urutan teknik pengawasan

Sumber: diolah peneliti 2019

\section{Kedudukan, Wewenang dan Kewajiban DPRD di Indonesia}

Lembaga legislatif di daerah (DPRD) berdasarkan UU No. 23 tahun 2014 mengalami perubahan posisi yang strategis sebagai lembaga penampung, penyalur sekaligus representasi aspirasi masyarakat di daerah. Sedangkan kedudukan DPRD sebagai unsur penyelenggara pemerintahan di daerah menyebutkan bahwa: "DPRD kabupaten/Kota merupakan lembaga perwakilan rakyat daerah yang berkedudukan sebagai unsur penyelenggara pemerintahan daerah kabupaten dan Kota. Masuknya DPRD dalam komposisi penyelenggara pemerintahan di daerah memberikan penjelasan bahwa dikotomi yang mengarah oposisi peran antara kepala daerah dengan DPRD mulai dihindari. Sedangkan kewajiban 


\section{REFORMASI}

ISSN 2088-7469 (Paper) ISSN 2407-6864 (Online)

Volume 10 Nomor 1 (2020)

DPRD sejalan dengan tugas DPR di Pemerintah Pusat. Revitalisasi peran Dewan Perwakilan Rakyat Daerah (DPRD) dapat dicermati dari UU No. 23 tahun 2014 tentang Pemerintahan Daerah, dimana Dewan Perwakilan Rakyat Daerah mendapatkan kewenangan membuat Peraturan Daerah (Perda), Penyusunan anggaran dan pengawasan sebagaimana yang diamanahkan dalam Pasal 41: "DPRD Kabupaten/ Kota mempunyai fungsi: (1) Legislasi, (2). Anggaran, dan Pengawasan“.

Kewenangan DPRD Berdasarkan UUPasal 343 ayat 1 UU Nomor 27 Tahun 2009 (UU Susduk) menyatakan, DPRD Kabupaten dan Kota memunyai fungsi legislasi, anggaran, dan pengawasan. Ayat 2 menjelaskan, ketiga fungsi sebagaimana dimaksud pada ayat 1 dijalankan dalam kerangka representasi rakyat di kabupaten/kota. Berbicara tugas dan fungsi DPRD berarti membahas tentang apa yang hendak diimplementasikan DPRD dalam upaya mencapai tujuanya untuk memberikan pelayanan publik.

Dalam pasal 344 ayat 1 UU No 27 Tahun 2009 menyatakan, tugas dan wewenang DPRD Kabupaten/Kota adalah, Membentuk peraturan daerah kabupaten/kota bersama bupati/walikota, Membahas dan memberikan persetujuan rancangan peraturan daerah mengenai anggaran pndapatan dan belanja daerah kabupaten/kota yang diajukan oleh bupati/walikota. Selain itu, melaksanakan pengawasan terhadap pelaksanaan peraturan daerah dan anggaran pendapatan dan belanja daerah kabupaten/kota, mengusulkan pengangkatan dan/atau pemberhentian bupati/walikota dan/atau wakil bupati/wakil walikota kepada Menteri Dalam Negeri melalui gubernur untuk mendapatkan pengesahan pengangkatan dan/atau pemberhentian.

Kemudian Hak DPRD Kabupaten/Kota diatur dalam pasal 349 ayat (1) UU No 27 Tahun 2009 DPRD kabupaten/kota yakni, Interpelasi, Angket dan Menyatakan pendapat. Pasal 350 UU No 27 Tahun 2009 menyatakan, Anggota DPRD kabupaten/kota memunyai hak, Mengajukan rancangan peraturan daerah kabupaten/kota, mengajukan pertanyaan, menyampaikan usul dan pendapat, memilih dan dipilih, membela diri, imunitas, mengikuti orientasi dan pendalaman tugas, Protokoler serta keuangan dan administratif.

\section{Hubungan Konsepsional Pengawasan DPRD dengan Eksekutif Dalam Pelayanan Publik}

Bila dipahami dari sisi manajemen pemerintahan, maka daerah otonom yang memiliki otonom daerah merupakan sebuah wujud pendelegasian wewenang dari pemerntah pusat kepada pemerintah daerah mengelola sumber daya negara dalam memudahkan penyediaan layanan pada masyarakat di daerah. Dengan demikian interaksi yang terjalin hubungan pemerintah pusat dan pemerintah daerah baik dalam wilayah maupun dalam hubungan administrasi dalam konteks wilayah pemerintah daerah dimaknai sebagai organ-self governing, yaitu council dan mayor yang para pejabatnya dipilih melalui proses pemilihan umum dengan dibatasi oleh wilayah yurisdiksinya, sedangkan dalam konteks administrasi, pemerintah daerah didekati dari sisi fungsi, yakni melaksanakan tugas dan kewenangan pelayanan publik pada hal-hal tertentu yang dirncikan dan sisanya merupakan kewenangan pemerintah pusat -local government.

Oleh karena Otonomi Daerah itu pula, maka DPRD diberikan kewenangan, antara lain melakukan pengawasan terhadap Pemerintah Daerah (pasal; 41 UU 32/2004). Pengawasan ini dengan tujuan untuk menciptakan kualitas prima pelayanan publik di daerah yang dapat memuaskan publik yang membutuhkan jasa layanan sekaligus sebagai sebuah bentuk pertanggungjawaban moral-politik kepada masyarakat yang diwakilinya. Dengan demikian pengawasan ini dilaksanakan tidak hanya karena terjadi masalah dalam suatu kegiatan pada Pemerintahan Daerah, tetapi karena memang harus dilaksanakan. Begitu juga dengan Pemerintah Daerah yang harus tetap memberikan keterangan pertanggungjawaban 


\section{REFORMASI}

ISSN 2088-7469 (Paper) ISSN 2407-6864 (Online)

Volume 10 Nomor 1 (2020)

atas semua tugas yang dijalankan itu kepada DPRD, karena ini merupakan amanat konstitusi (Pasal 27 ayat 2 UU 32/2004).

\section{Bentuk Pelaksanaan Mekanisme Pengawasan Represif}

Pengawasan represif jika merunut pada elemen dalam teori yang dikemukakan oleh Griffin biasa dilakukan sebelum atau setelah ada pengaduan dari penerima layanan. Bila dilakukan sebelum ada aduan, tindakan represif biasanya didasari oleh keinginan anggota DPRD untuk melakukan pengukuran kinerja atau membandingkannya dengan standar yang telah ditetapkan.Sedangkan pengawasan yang dilakukan setelah adanya aduan acapkali terjadi dibanyak daerah apabila terjadi ketidakpuasan yang berulang. Dalam konteks pelayanan di RSUD Pamekasan, tindakan turun tangan langsung oleh anggota dewan seyogyanya tidak terjadi berulang kali. Meski bernilai positif, hal itu sesungguhnya mengindikasikan tidak adanya evaluasi yang efektif sehingga "membuka peluang" terjadinya kejadian yang serupa diwaktu yang akan datang.

Melihat kondisi tersebut, upaya pemberian reward dan punishment bisa jadi patut dipertimbangkan sebagai bagian dari evaluasi dan pengawasan preventif ditahun yang akan datang. Meski pengawasan represif bisa dikategorikan sebagai pengawasan melekat, secara internal pengawasan ini tak bisa dipisahkan dengan pengawasan preventif yang lebih condong pada trilogi fungsi anggota DPRD.Untuk itu perlu kiranya dibentuk sistem yang lebih mendasar sehingga keduanya saling melengkapi.

Jika terbentuk dalam sistem yang kuat, fungsi pengawasan oleh DPRD terhadap pelaksanaan layanan publik akan lebih sering dibicarakan sisi preventifnya. Hal ini dikarenakan ketika layanan publik semakin membaik, tindakan-tindakan pengawasan represif secara otomatis akan semakin jarang dilakukan. Pemerintah (dalam hal ini DPRD) "hanya" perlu lebih kreatif dan jeli melihat setiap celah buruk pelayanan, lalu memasukkan setiap solusi yang mungkin bisa dilakukan sehingga bisa disebut menjadi bagian dari pengawasan preventif.

\section{Pelaksanaan Fungsi Pengawasan DPRD Pada Pelayanan Publik di Kabupaten Pamekasan}

Terminologi kontrol dalam bahasa Inggris berasal dari kata control yang berarti pengawasan, dalam ilmu manajemen, konsep supervisi menjadi bagian unsur dalam kegiatan pengelolaan. Dalam hukum publik, supervisi memiliki makna sebagai kegiatan mengawasi secara seksama. Sama halnya dengan pendapat Suriansyah Murhani (2008:2) bahwa pengawasan tidak lain adalah berbagai aktivitas yang telah digariskan dalam peraturan perundang-undangan maka dapat dilaksanakan secara baik dalam arti sesuai dengan apa yang dimaksud.

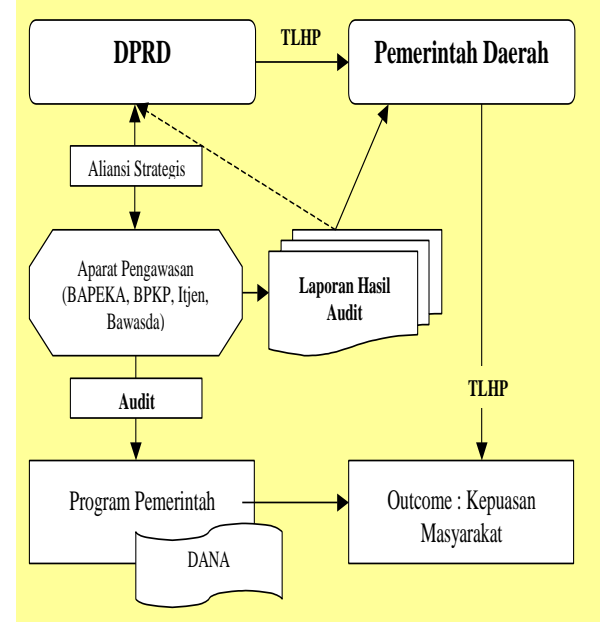

Gambar 2. Jaringan Kerjasama dengan Institusi Pengawasan

Sumber: diolah peneliti 2019 


\section{REFORMASI}

ISSN 2088-7469 (Paper) ISSN 2407-6864 (Online)

Volume 10 Nomor 1 (2020)

Relasi pengawasan atau supervisi dengan penyelenggaraan Pemerintah Daerah pada dasarnya bahwa adalah upaya kegiatan memahami sekaligus menilai realita faktual menyangkut pelaksanaan kesesuaian program. Secara eksplisit kerrja pengawasan adalah mencakup seluruh kegiatan menilai suatu pelaksanaan tugas secara de facto yang bertujuan sebagai media terbatas untuk melakukan semacam cross check atau pencocokan apakah kegiatan yang dilaksanakan telah sesuai dengan tolak ukur yang telah ditentukan sebelumnya atau tidak, demikian pula dengan tindak lanjut dari hasil pengawasan tersebut.

Dalam penyelesaian suatu permasalahan di Pemerintah Daerah,DPRD dapat meminta pertanggungjawaban Bupati dan apabila pertanggungjawaban tidak dapat di terima, DPRD dapat mengusulkan pemberhentian Bupati. Berdasarkan dokumen dan hasil wawancara menunjukkan tindak lanjut hasil pengawasan belum banyak memberikan koreksi terhadap penyimpangan atau kesalahan yang terjadi.

Kesimpulan yang menunjukkan bahwa pelaksanaan fungsi pengawasan DPRD Kabupaten Pamekasan belum menerapkan mekanisme pengawasan yang sistematis artinya walaupun dalam pengawasan yang di laksanakan tiap komisi terjadwal oleh sekretariat dewan namun tidak sebagian besar hasil pengawasan tidak di tindak lanjuti sesuai mekanisme di DPRD. Rapat dengar pendapat atau hearing, kunjungan kerja baik yang resmi ataupun sidak serta pengaduan masyarakat belum disusun dengan pola kegiatan yang sistematis, artinya langkah mana yang di dahulukan ketika menindak lanjuti temuantemuan yang ada dari hasil pengawasan belum di atur secara tegas dan secara teknis.

Tindakan yang dilakukan oleh lembaga publik ini tidak lepas dengan yang namanya tujuan terhadap apa yang sudah menjadi tugas dan fungsinya,namun dalam hal ini bagaimana pelaksanaan fungsi pengawasan DPRD terhadap pelayanan publik di Kabupaten Pamekasan, dalam bahasan ini mengutip dari pendapat (Ndraha, 1990:111) yaitu Aspek dinamis lembaga atau peranan mewakili tata institusional suatu lembaga"berasarkan kutipan tersebut menjelaskan bahwaperanan lembaga dihubungkan dengan jabatan atau kedudukan seseorang selama orang tersebut menduduki suatu jabatan",jadi peran lembaga yang di duduki itu,seperti DPR, DPRD, DPD dan MPR yang namanya tugas dan fungsi melekat didalamnya dan tanggung jawab. Dalam hal ini seperti berpengaruh pada pola pengawasan yang dijalankan DPRD Mengarah pada tindakan yang di lakukan komisi DPRD dalam kontek menjalankan tugas dan fungsinya.

Dari semua sinergi yang sudah menjadi target dalam proses pengawasan DPRD secara keseluruhan belum mampu mengaplikasikan manajemen yang maksimal, dimana semestinya dalam pengawasan ini terangkum dalam perencanaan orgnisasi, atau kita kenal dengan istilah POAC (Planning, Organizing, Actuating, Controling). Pengawasan ini atau controling lebih menekankan dalam proses pengoreksian terhadap jalannya suatu agenda yang sudah di rencanakan. Koonzt seperti yang di kutip oleh (Wasistiono dan Wiyoso,2009:143) Pengawasan di artikan "Controlingin measurement and correction of performance in order to make sure that enterprisen objectives and paln divise to attain them are being accompalished" yang terkoneksikan bahwa sebuah control ini berguna untuk mengukur efektivitas dari tindakan atas kinerja yang sudah berjalan dalam mencapai target sesuai sasaran.

\section{Faktor Pendukung}

Fenomena-fenomena yang tergambar dalam deskripsi tentang faktor-faktor pendukung dapat diinterpretasikan bahwa pelaksanaan fungsi pengawasan DPRD terhadap pelayanan publik di daerah berjalan optimal karena didukung oleh adanya aturan-aturan yang memungkinkan bagi Komisi IV dan I DPRD untuk menjalankan wewenang, da kewajiban yang diemban, adanya komitmen anggota DPRD untuk melaksanakan fungsi pengawasan, dan tidak ada dominasi kursi oleh partai politik di DPRD. 


\section{REFORMASI}

ISSN 2088-7469 (Paper) ISSN 2407-6864 (Online)

Volume 10 Nomor 1 (2020)

\section{Faktor Penghambat}

Kesimpulan hasil penelitian tentang faktor penghambat menunjukkan bahwa faktor penghambat bagi Komisi IV dalam melakukan kegiatan pengawasan adalah komitmen pimpinan SKPD yang jarang menghadiri pemanggilan Komisi IV untuk turun ke lapangan, ketersediaan pendukung fasilitas yang belum cukup atau rendah. Kesimpulan diatas menunjukkan bahwa ada dua hal utama yang berpotensi menjadi penghambat berfungsinya DPRD, yaitu jabatan dan kekuatan sosial (social power). Adapun beberapa hal yang perlu ditingkatkan khususnya terhadap aspek pengelolaan fungsi pengawasan DPRD sebagaimana yang akan dibahas pada sub pembahasan di bawah ini.

\section{KESIMPULAN}

Dengan mengacu pada rumusan pembahasan di atas, maka terdapat kesimpulan yang meliputi bebera hal sebagai berikut:

1. Pelaksanaan Fungsi DPRD dalam Pengawasan. Pelaksanaan fungsi pengawasan DPRD Kabupaten Pamekasan belum menerapkan mekanisme pengawasan yang sistematis artinya walaupun dalam pengawasan yang di laksanakan tiap komisi terjadwal oleh sekretariat dewan namun tidak sebagian besar hasil pengawasan tidak di tindak lanjuti sesuai mekanisme di DPRD.

2. Wujud nyata pelaksanaan pengawasan DPRD terhadap pelayanan publik di Kabupaten Pamekasan yaitu diadakannya Audiensi antara DPRD Kabupaten Pamekasan dengan beberapa kolompok masyarakat (NGO) dan pihak lain di Kabupaten Pamekasan.

Faktor pendukung DPRD sebagai mitra Pemerintah Daerah dalam mensejahterakan rakyat dengan menjalankan fungsi pengawasan, dukungan pendanaan dan imunitas yang berkaitan dengan jaminan dan perlindungan hukum atas apa yang dilakukan DPRD terkait pelaksanaan tugas,fungsi dan wewenangnya, ketersediaan fasilitas DPRD Pamekasan yang memadai dalam menjalankan tugas pengawasan mustinya menjadi perioritas pendukung pelaksanaan tugas. Fasilitas yang dimaksud untuk menunjang kegiatan pengawasan DPRD berupa kendaraan Dinas, anggaran untuk kegiatan dewan, tunjangan komunikasi dan fasilitas penunjang lainnya, anggota DPRD mempunyai hak untuk mengikuti Diklat keorganisasian, Bimbingan Teknis, Simposium, Kunjungan dalam negeri dan fasilitas lainnya yang mendukung untuk meningkatkan kegiatan pengawasan DPRD, juga di dukung oleh Tim Sekretariat Dewan; dalam proses menjalankan tugas dan fungsinya, alat kelengkapan dibantu oleh sekretariat dewan.

Sementara faktor penghambat DPRD dalam pelaksanaan fungsinya terhadap pengawasan pelayanan publik di Kabupaten Pamekasan yaitu belum adanya sistem dan prosedur baku pengawasan DPRD, sedikit tindak lanjut hasil pengawasan DPRD, belum adanya mekanisme penyampaian informasi syarakat sebagai salah satu alat pengawasan, kurangnya kemampuan teknis anggota dalam pengawasan, sistem pemilihan anggota DPRD. faktor lain penyebab rendahnya fungsi pengawasan DPRD antara lain; (1).Rendahnya kualitas sumber daya manusia; (2). Rendah kemampuan manajerial atau kepemimpinan; (3). Rendahnya faktor dukungan kontrol masyarakat; (4). Keterbatasan dana; (5). Rendahnya konsisten, komitmen dan movitavasi anggota DPRD.

\section{DAFTAR PUSTAKA}

Denhardt, J. V., \& Denhardt, R. B. (2003). The New Public Service. Serving, Not Steering, ME Sharpe. Inc, New York.

Muluk, M. R. K. (2009). Peta konsep desentralisasi \& pemerintahan daerah. ITSPress bekerjasama dengan Lembaga Penerbitan \& Dokumentasi, FIA, Unibraw. 


\section{REFORMASI}

ISSN 2088-7469 (Paper) ISSN 2407-6864 (Online)

Volume 10 Nomor 1 (2020)

Hadari, N. (1995). Pengawasan Melekat di Lingkungan Aparatur Pemerintah. Jakarta: Erlangga.

Ndraha, T. (1997). Metodologi ilmu pemerintahan. Jakarta: Rineka Cipta.

Satori, D. an dan Aan Komariah, 2009. Metodologi penelitian kualitatif.

Utomo, W. (2007). Administrasi publik baru Indonesia: perubahan paradigma dari administrasi negara ke administrasi publik. Pustaka Pelajar.

Wasistiono, S., \& Riyani, O. (2009). Etika Hubungan Legislatif-Eksekutif Dalam Rangka Pelaksanaan Otonomi Daerah. 